\title{
PEMODELAN MATEMATIKA ALIRAN UDARA PADA PARU-PARU AKIBAT PENYAKIT CORONAVIRUS DISEASE 2019 (COVID-19)
}

\author{
Yogi Setiawan ${ }^{1}$, Arif Fatahillah ${ }^{2}$, Arika Indah Kristiana ${ }^{2}$ \\ Program Studi Pendidikan Matematika, FKIP, Universitas Jember \\ Jalan Kalimantan 37 Kampus Tegalboto Jember 68121 \\ E-mail: yogisetyawan11@mail.com
}

\begin{abstract}
The bronchial airways are an important part of the respiratory system, it is not uncommon for the bronchi to experience disturbances, one of the disorders due to coronavirus diseases (Covid-19). Coronavirus diseases (Covid-19) are what cause narrowing of the bronchial tubes so that they will interfere with the speed of airflow. This airflow speed will be modeled with mathematical language. The mathematical model of airflow velocity in this study is formed based on equations of momentum equations which are then solved by the finite element method. Speed analysis airflow was simulated using MATLAB and FLUENT software. The problems studied are the effect of the narrowing diameter, initial velocity, and viscosity on the air flow velocity. Based on the research results show that the smaller the narrowing diameter and the viscosity of the incoming air, the greater the airflow velocity, while the greater the initial velocity, the greater the resulting airflow velocity.
\end{abstract}

Keywords: Coronavirus Diseases 2019 (Covid-19), bronchial, lungs, airways, finite element method.

\section{PENDAHULUAN}

Matematika merupakan suatu ilmu yang menjadi dasar dan pengembangan dalam ilmu pengetahuan lainya [1]. Tujuan dari pengembangan ilmu lainya yaitu untuk mengubah suatu teori yang bersifat abstrak kedalam hal yang bersifat konkret. Matematika juga digunakan sebagai cara untuk mendapatkan jawaban dari suatu permasalahan dalam dunia nyata dan bidang ilmu lain, salah satunya yaitu bidang kedokteran [1].

Kedokteran merupakan salah satu pengembangan ilmu matematika di dalam kedokteran mempelajari terkait cara penyakit itu menyebar dalam kehidupan sehari-hari dan terkait penyembuhanya [2]. Secara garis besar, terdapat dua faktor yang menyebabkan orang dapat sakit diantaranya faktor internal dan faktor eksternal. Faktor internal merupakan faktor berasal dari dalam tubuh manusia itu sendiri seperti penyakit yang berasal dari gen dan keturunan. Faktor eksternal merupakan faktor yang berasal dari luar tubuh manusia, contohnya seperti Particulate Matter 2.5. Di dalam PM 2.5 terdiri dari beberapa peleburan Industri logam $\mathrm{Pb}$, campuran industri peleburan logam dan garam laut, debu tanah, polusi akibat trasnportasi serta pembakaran biomassa . Particulate Matter 2.5 tidak hanya dikarenakan partikel debu melainkan bakteri dan virus yang terbawa oleh udara dan mengendap di saluran pernapasan contohnya Coronavirus Disease 2019 (Covid-19) [3].

\footnotetext{
${ }^{1}$ Mahasiswa S-1 Prodi Pendidikan Matematika FKIP Universitas Jember

${ }^{2}$ Dosen Prodi Pendidikan Matematika FKIP Universitas Jember
} 
Penyakit Coronavirus Disease 2019 (Covid-19) merupakan penyakit yang menular dan disebabkan oleh sindrom pernafasan akut yang parah yaitu coronavirus-2 (SARS-CoV-2). Awal mula virus ini muncul di kota Wuhan, Cina dan menyebar ke seluruh dunia. Analisis gen mengungkapkan bahwa SARSCoV-2 secara filogenetik yang disebabkan oleh kelelawar seperti sindrom pernapasan akut mirip virus SARS dan MERS. Penyakit karena ini disebut Covid-19. Virus ini bisa menyebabkan gangguan ringan pada sistem pernapasan, infeksi paru-paru yang berat, hingga kematian jika tidak ditangani dengan cepat [4].

Model matematika adalah proses untuk mempresentasikan dari sistem nyata yang dijabarkan dalam bentuk, himpunan, konstanta, variabel, simbol dan persamaan matematika [1][5]. Pemodelan matematika merupakan usaha dalam perancangan rumusan matematika yang menggambarkan untuk mendapatkan penyelesaian masalah matematika yang digeneralisasi untuk diterapkan pada perilaku atau kejadian alam [2]. Syarat penting yang dibutuhkan dalam penyelesaian matematika untuk menghasilkan solusi adalah syarat keadaan suatu benda, syarat ketunggalan dalam variabel, dan syarat kekontinuan pada parameter [6].

Proses masuknya Coronavirus Disease 2019 (Covid-19) ini diakibatkan dengan penularan secara langsung dengan pasien positif Coronavirus Disease 2019 (Covid-19) lalu virus ini menyebar melalui system pernapasan manusia yang mana dimulai dari hidung, faring, laring, trakea, bronkus, bronkiolus, dan ke alveolus. Virus ini akan mengendap pada system pernapasan manusia apabila tidak cepat ditangani [7]. Penelitian ini mengembangkan parameter dari penelitian sebelumnya. Pada penelitian yang dilakukan oleh Justu Mutuku et.al hanya terkait pengaruh kecepatan dan bilangan Reynolds terhadap kecepatan aliran akibat Coronavirus Disease 2019 (Covid-19). Oleh karena itu penelitian ini mengembangkan variabel terkait bagaimana pengaruh diameter penyempitan, kecepatan awal, dan viskositas udara.

Penelitian ini bertujuan membentuk dan mengembangkan model matematika aliran udara pada paru-paru akibat Coronavirus Disease 2019 (Covid-19) . Model matematika akan diselesaikan menggunakan metode elemen hingga. Metode elemen hingga merupakan salah satu metode pendekatan numerik yang mendasarkan dalam permasalahan pada tiap-tiap elemen bagian yang dinamakan elemen hingga [8], [9]. Setiap permasalahan dalam objek benda yang ada akan diselesaikan dengan pendekatan kuadratik, dimana bentuk penyelesaian dari metode elemen hingga memiliki bentuk persamaan matriks dengan ordo nxn [5]. Selain itu diharapkan untuk menambah wawasan pengetahuan dalam bidang pemodelan matematika, memberikan kontribusi terhadap berkembangnya pengetahuan baru dalam bidang pemodelan matematika menggunakan metode elemen hingga.

\section{METODE PENELITIAN}

Metode penelitian adalah tahap yang dilakukan untuk mendapatkan data yang akan dianalisis untuk sampai pada kesimpulan yang sesuai dengan tujuan dari penelitian. Pada penelitian ini merupakan jenis penelitian simulasi. Penelitian simulasi adalah sebuah replikasi atau visualisas dari perilaku sebuah sistem. Secara umum simulasi merupakan kegiatan untul mendapatkan sebuah model yang berisi tentang variabel-variabel apa saja yang menampilkan ciri utama dari sistem kehidupan nyata.

Pada penelitian ini memodelkan aliran udara pada paru-paru akibat penyakit Coronavirus Disease 2019 (Covid-19) sehingga diperoleh hasil atau data-data yang mendekati keadaan sebenarnya. Langkah pertama adalah observasi terkait aliran udara 
pada paru-paru akibat penyakit Coronavirus Disease 2019 (Covid-19) , menentukan faktor yang mempengaruhi aliran udara. Langkah selanjutnya membuat persamaan dari sistem nyata tersebut dalam model matematika. Maka akan diperoleh model matematika aliran udara pada paru-paru akibat penyakit Coronavirus Disease 2019 (Covid-19).

\section{HASIL PENELITIAN}

Analisis numerik aliran udara pada paru-paru akibat penyakit Coronavirus Disease 2019 (Covid-19) dilakukan dengan beberapa tahapan. Tahap pertama yaitu pembentukan model matematika aliran udara pada paru-paru akibat penyakit Coronavirus Disease 2019 (Covid-19) didasarkan pada persamaan momentum. Persamaan momentum merupakan bentuk persamaan diferensial yang menghubungkan gaya-gaya yang bekerja pada volume kendali, salah satunya adalah tekanan $P$ dan hukum Stokes

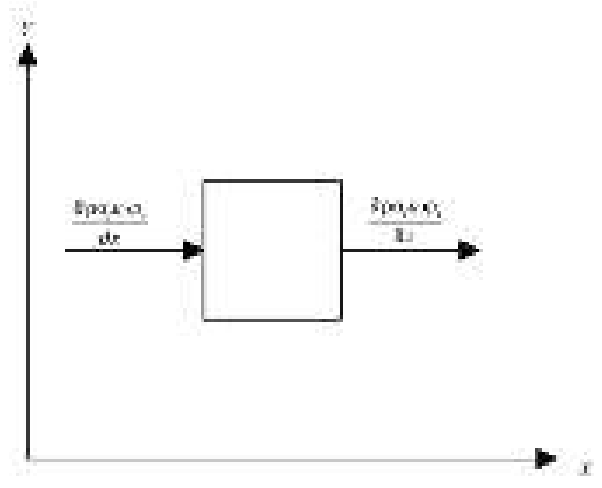

\section{Gambar 1. Skema Kendali Persamaan Momentum}

Maka persamaan momentum yang diperoleh sebagai berikut

$$
\begin{gathered}
\frac{\partial \rho \alpha_{f} u \phi_{0}}{\partial t}+[\text { pure }- \text { rate }]=\sum F \\
\frac{\partial \rho \alpha_{f} u \phi_{0}}{\partial t}+[\text { out }-i n]=\sum F \\
\frac{\partial \rho \alpha_{f} u \phi_{0}}{\partial t}+\left[\frac{\partial \rho \alpha_{f} u \phi_{e}}{\partial t}-\frac{\partial \rho \alpha_{f} u \phi_{w}}{\partial t}\right]=\sum F
\end{gathered}
$$

Sigma Force $\left(\sum F\right)$ merupakan gaya-gaya yang bekerja pada persamaan momentum. Gaya-gaya yang bekerja antara lain.

1. Gaya tekanan atau pressure $(\mathrm{P})$

2. Gaya kekentalan suatu zat $(\mu)$

3. Hukum Stokes $\left(S t k_{n}\right)$ [10]

Sehingga, persamaan gaya yang bekerja adalah.

$$
\sum F=-\alpha_{f} \nabla P+\alpha_{f} \sigma_{x}+S t k_{n}
$$

dimana :

$$
\begin{aligned}
& \nabla P=\frac{\partial P}{\partial x} \\
& \sigma_{\mathrm{x}}=\mu \frac{\partial u}{\partial x}
\end{aligned}
$$




$$
S t k_{n}=\frac{2 Q \rho_{p} d^{2}}{9 \pi \mu D_{\text {ave }}^{3}} C_{c} \alpha_{f}
$$
berikut.

Dengan mensubtitusikan persamaan (5) ke persamaan (4), didapatkan persamaan

$$
\sum F=-\alpha_{f} \frac{\partial P}{\partial x}+\alpha_{f} \mu \frac{\partial u}{\partial x}+\frac{2 Q \rho_{p} d^{2}}{9 \pi \mu D_{a v e}{ }^{3}} C_{c} \alpha_{f}
$$

Model matematika aliran udara pada paru-paru akibat penyakit Coronavirus Disease 2019 (Covid-19) diperoleh dengan mensubtitusi persamaan (3) dan persamaan (6). Maka diperoleh model matematika sebagai berikut:

$$
\begin{aligned}
& \frac{\partial \rho \alpha_{f} u \phi_{0}}{\partial t}+\left[\frac{\partial \rho \alpha_{f} u \phi_{e}}{\partial t}-\frac{\partial \rho \alpha_{f} u \phi_{w}}{\partial t}\right]=-\alpha_{f} \frac{\partial P}{\partial x}+\alpha_{f} \mu \frac{\partial u}{\partial x}+\frac{2 Q \rho_{p} d^{2}}{9 \pi \mu D_{\text {ave }}{ }^{3}} C_{c} \alpha \\
& \frac{\partial \rho u \phi_{0}}{\partial t}+\left[\frac{\partial \rho u \phi_{e}}{\partial t}-\frac{\partial \rho u \phi_{w}}{\partial t}\right]=-\frac{\partial P}{\partial x}+\mu \frac{\partial u}{\partial x}+\frac{2 Q \rho_{p} d^{2}}{9 \pi \mu D_{\text {ave }}{ }^{3}} C_{c}
\end{aligned}
$$

\section{KESIMPULAN}

Berdasarkan penelitian yang telah dilakukan untuk mengkaji aliran udara lebih baik lagi diharapkan penelitian yang sejenis bisa mengembangan variabel-variabel yang terkait aliran udara. Model matematika aliran udara pada paru-paru akibat penyakit Coronavirus Disease 2019 (Covid-19) diperoleh dari persamaan massa yang memiliki resultan gaya sebesar nol dan momentum. Dari hasil penelitian maka diperoleh model matematika aliran udara pada paru-paru akibat penyakit Coronavirus Disease 2019 (Covid-19)

$$
\frac{\partial \rho u \phi_{0}}{\partial t}+\left[\frac{\partial \rho u \phi_{e}}{\partial t}-\frac{\partial \rho u \phi_{w}}{\partial t}\right]=-\frac{\partial P}{\partial x}+\mu \frac{\partial u}{\partial x}+\frac{2 Q \rho_{p} d^{2}}{9 \pi \mu D_{\text {ave }}{ }^{3}} C_{c}
$$

Model matematika diperoleh berdasarkan faktor-faktor yang mempengaruhi kecepatan aliran udara. Model matemetika dapat disimulasikan untuk memperoleh hasil numerik yang dapat dibandingkan dengan nilai eksak dan keadaan sebenernya pada kehidupan nyata, sehingga penelitian yang dilakukan orang lain dapat melakukan simulasi model matematika yang diperoleh.

\section{DAFTAR PUSTAKA}

[1] Putra, A. S. H., Suharto \& Fatahillah, A. (2017). Analisis Sirkulasi Udara pada Sistem Pernafasan Manusia Menggunakan Metode Volume Hingga. Kadikma, 8(2), 95-104.

[2] Fatahillah, A., Setiawani, S., Mandala, A. S., Suharto, S., Murtikusuma, R. P., Safrida, L. N., Hussen, S. \& Adawiyah, R. (2019). Numerical analysis of blood flow in intracranial artery stenosis affected by ischemic stroke using Finite Element method. J. Phys. Conf. Ser., 1218 (1), 012005. doi: 10.1088/17426596/1218/1/012005.

[3] Chen, W. H., Lee, K. H., Mutuku, J. K., \& Hwang, C. J. (2018). Flow dynamics 
and PM2.5 deposition in healthy and asthmatic airways at different inhalation statuses. Aerosol Air Qual. Res., 18(4), 866-883. doi: 10.4209/aaqr.2018.02.0058.

[4] Shereen, M. A., Khan, S., Kazmi, A., Bashir, N., \& Siddique, R. (2020). COVID19 infection: Origin, transmission, and characteristics of human coronaviruses. $J$. Adv. Res., 24, 91-98. doi: 10.1016/j.jare.2020.03.005.

[5] Hardiyanti, S. A., Dafik, \& Fatahillah, A. (2015). Analisis Kecepatan Aliran Hidrogen Peroksida (H2o2) Pada Sterilisasi Saluran Akar Gigi Menggunakan Metode Numerik Volume Hingga. Kadikma, 6(2), 13-26.

[6] Brahmanto, J., Fatahillah, A., \& Dafik. (2017). Pemodelan Matematika Aliran Fluida Pada Radiator Mobil Tipe Sr (Single Row). Kadikma, 8(1), pp. 112-117.

[7] Mutuku, J. K., Hou, W. C., \& Chen, W. H. (2020). An overview of experiments and numerical simulations on airflow and aerosols deposition in human airways and the role of bioaerosol motion in covid-19 transmission. Aerosol Air Qual. Res., 20(6), 1172-1196. doi: 10.4209/aaqr.2020.04.0185.

[8] Fatahillah, A., Dafik, D., Prawoto, B. P., \& Lazuardi, A. R. (2018). Numerical analysis of fluidal flow in heat exchangers using finite element method to reduce exhaust emission level in air. J. Phys. Conf. Ser., 1108(1), 012089. doi: 10.1088/1742-6596/1108/1/012089.

[9] Fatahillah, A. (2010). Pendahuluan Persamaan Dasar. Kadikma, 2(1), pp. 71- 80.

[10] Choi, S., Miyawaki, S., \& Lin, C. L. (2018). A Feasible Computational Fluid Dynamics Study for Relationships of Structural and Functional Alterations with Particle Depositions in Severe Asthmatic Lungs. Comput. Math. Methods Med., 2018. doi: $10.1155 / 2018 / 6564854$. 